\title{
POPULATION DYNAMICS FACTORS OF UNGULATES AND WOLVES OF THE SARATOV REGION IN THE $21^{\text {st }}$ CENTURY
}

\author{
Mikhail L. Oparin ${ }^{1}$, Igor A. Kondratenkov ${ }^{1}$, Olga S. Oparina ${ }^{1}$, \\ Sergey V. Sukhov ${ }^{2}$, and Askhat B. Mamaev ${ }^{1}$ \\ ${ }^{I}$ Saratov branch of A. N. Severtsov Institute of Ecology and Evolution, \\ Russian Academy of Sciences \\ 24 Rabochaya Str., Saratov 410028, Russia \\ ${ }^{2}$ Committee of Hunting and Fishing of the Saratov Region \\ 47-55 Universitetskaya Str., Saratov 410012, Russia \\ E-mail:oparinml@mail.ru
}

Received 28 July 2018, revised 16 August 2018, accepted 29 August 2018

\begin{abstract}
Oparin M. L., Kondratenkov I. A., Oparina O. S., Sukhov S. V., Mamaev A. B. Population Dynamics Factors of Ungulates and Wolves of the Saratov Region in the $21^{\text {st }}$ Century. Povolzhskiy Journal of Ecology, 2018, no. 4, pp. 433-446 (in Russian). DOI: https://doi.org/10.18500/16847318-2018-4-433-446
\end{abstract}

The paper is devoted to studying of the relations between the formation of "private" hunting grounds, the increase in the density of ungulates and the decline in the numbers of wolves, and the role of other factors determining the abundance of these game animals. Six ungulate species constantly live in the Saratov Region, namely: the elk (Alces alces L.), the red deer (Cervus elaphus L.), the axis deer (Cervus nippon Temminck), the roe deer (Capreolus capreolus L.), the Tartarian roe (Capreolus pygargus Pallas), and the wild boar (Sus scrofa L.). All these species, except the red deer, are commercial. The roe deer is a rare species listed in the Red Data Book of the Saratov Region. The population dynamics of the ungulates and wolf in the described region was studied using winter field records and official data on animals shooting for the period from 2001 till 2018. The abundance of all the ungulate species for this period has increased significantly, whilst the numbers of wolves, on the contrary, have decreased. The influence of several factors, both natural and anthropogenic, on the population dynamics of the mentioned species was analyzed. First of all, the impact of official hunting on the game species was considered. Of all the factors examined, only one influenced directly the population dynamics of wild ungulates in the Saratov region at the beginning of this century. The very strong direct correlation between the increase in the area of hunting grounds assigned to private hunting managers, and the increase in the numbers of wild ungulates undoubtedly speaks for their causal relationship.

Key words: "private" hunting ground, ungulates, wolf, population dynamics of game animals, natural and anthropogenic factors.

DOI: https://doi.org/10.18500/1684-7318-2018-4-433-446

\section{INTRODUCTION}

Ungulates are the most important resource of hunting in the country. To ensure their sustainable existence and use, it is necessary to study the population dynamics of species belonging to this group. Of particular importance is the determination of major factors affecting the number of ungulates (Watt, 1971; Caughley, 1979; Riklefs, 1979; Lomanov, 1995). In addition to environmental conditions, anthropogenic factors can play a significant role in regulation of their abundance, not only hunting, but also the development of hunting legislation, the organization of the use of game animals, their protection, etc. (Danilkin, 2007, 2009).

(C) Oparin M. L., Kondratenkov I. A., Oparina O. S., Sukhov S. V., Mamaev A. B., 2018 
Ungulates are main food supply for the wolf. And this predator is also an object of hunting. At the beginning of XXI century almost synchronous increase in the density of ungulates and decrease in the number of wolves in Saratov Region was observed. At this time, the institute of modern hunting management, i.e. private hunting grounds, began to form in the region. Its formation became possible after the adoption of the Federal Law "On the Animal World" in 1995. In the Saratov Region, the first private hunting grounds appeared in 2000, and the process of their intensive formation was basically completed by 2010 . It should be noted that in Soviet times there were no private hunting grounds. At that time, hunting grounds assigned to local teams of hunters from large industrial enterprises or hunting reserves of regional significance can be considered as some analogue of Private enterprises.

The main goal of this study was to reveal connection between the formation of private hunting grounds, the increase in the density of ungulates and the decline in the number of wolves, and to find out the role of other factors in the dynamics of their abundance.

\section{MATERIAL AND METHODS}

The official credentials of the state service for accounting of hunting resources in Russia and the Saratov Region published in departmental reports, information and analytical materials, the State Hunting Register and in State and Environmental Protection Reports of the Saratov Region were used in the analysis. It should be noted that information on the number of game animals and especially on their harvest differ in various sources. This is due to different methods of data collection and their further processing. For example, the basis for estimating the number of game animals is the data of winter field records, however, for the State Hunting Register additional data from other types of accounting and expert assessments are used.

In addition, the materials of the relevant resolutions of the Governor and the Government of the Saratov Region on attributing hunting grounds for long-term use of wildlife objects, and also reports of regional authorities on the conclusion of hunting estate agreements, were considered.

When analyzing the dynamic series of numbers, it is especially important that the data should be of the same type for the entire considered period. In this regard, we have chosen data on the number of game animals based on the winter field records, processed by specialists of the regional accounting service. When processing data, routes were executed that were made with methodical violations and with sharply evading indicators.

When analyzing data on hunting animals, in case of discrepancies in different sources, preference was given to the information specified in the State Hunting Register. Information about the death of animals is not available for all years of the considered period. If this information was presented in several sources, then those data were selected where the number of identified deaths was maximum by year for specific species. Data on weather conditions for specific years and individual climate parameters were obtained from the website of the All-Russian Scientific Research Institute of Hydro meteorological Information - the World Data Center "Federal Service for Hydrometeorology and Environmental Monitoring..." (2018). Information on crop yields in the Saratov 


\section{POPULATION DYNAMICS OF UNGULATES AND WOLVES}

Region was obtained from the website of the Federal State Statistics Service (2018), and from the data contained in the "Concept for the development of the agro-industrial complex of the Saratov Region until 2020 (http://www.minagro.saratov.gov.ru/Razvitie/).

In this paper, data on the numbers of ungulates and wolves are given as of March 1, of death - on December 31, and on the attribution of hunting grounds - on January 1 of the corresponding year. When displayed together, data on the extraction of animals were combined with data on their numbers for the first year of the corresponding hunting season.

Statistical data processing was carried out using Excel and Statistica programs. The calculation of average annual population growth rates was determined using the least squares method.

\section{RESULTS AND DISCUSSION}

In the Saratov Region, six species of ungulates constantly live - elk (Alces alces L.), red deer (Cervus elaphus L.), axis deer (Cervus nippon Temminck), roe deer (Capreolus capreolus L.), Tartarian roe (Capreolus pygargus Pallas) and wild boar (Sus scrofa L.). All species, except roe deer, are commercial. Roe deer is a rare species listed in the Red Data Book of the Saratov Region.

The dynamics of the number of ungulates and wolf populations on the territory of the Saratov Region, according to winter field records and their official harvest for the period from 2001 to 2018 is presented in Figure 1. The population of all species of ungulates during the period under review increased significantly, and abundance of wolf, on the contrary, decreased.

The number of elk increased approximately twice from 2220 to 4760 individuals. The fastest growth rate in the elk population, an average of $9 \%$ per year, were observed from 2006 to 2013. Until this period, the state of the elk population can be considered stable, and after that, stabilizing. The number of red deer also increased about two times: from 630 to 1400 individuals. The fastest growth rate of the population of red deer, on average by $9 \%$, was observed from 2005 to 2013 , and then its number began to stabilize. The abundance of axis deer increased about four times from 360 to 1580 individuals. The fastest rate of population growth of this species on average by $13 \%$ per year, was observed in the period from 2009 to 2017 . The growth of the number of this species continues to the present. The number of Tartarian roe has increased about three times from 4,770 to 15,780 individuals. The fastest growth rate of Tartarian roe, an average of $10 \%$ per year, was observed from 2002 to 2012 . Recently, signs of stabilization of the population of this species are observed. The boar population increased from 6540 to 14920, but then decreased to 3050 individuals. The fastest growth rate in the wild boar population, an average of $27 \%$ per year, was observed in the period from 2006 to 2008, and declines in the period from 2015 to 2017. The number of wolves was reduced from about 230 to 24 , but then increased to 135 individuals. The fastest rate of decline in the wolf population, an average of $23 \%$ over the year, was observed in the period from 2003 to 2013, and its growth - in the period from 2016 to the present. We found that a sufficiently synchronous increase in the number of ungulates on the territory of the Saratov Region with a simultaneous decrease in the number of the wolf was observed in the period from 2001 to 2015 . 
Mikhail L. Oparin, Igor A. Kondratenkov, Olga S. Oparina et al.
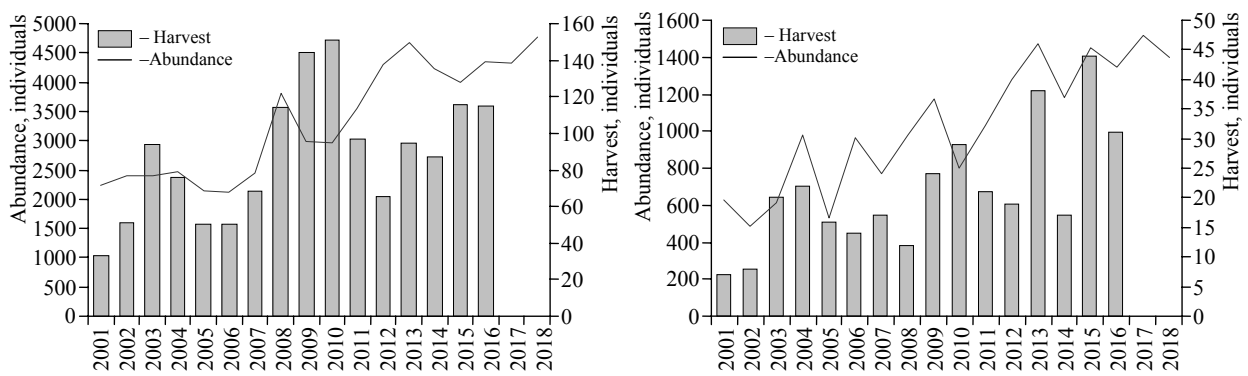

a
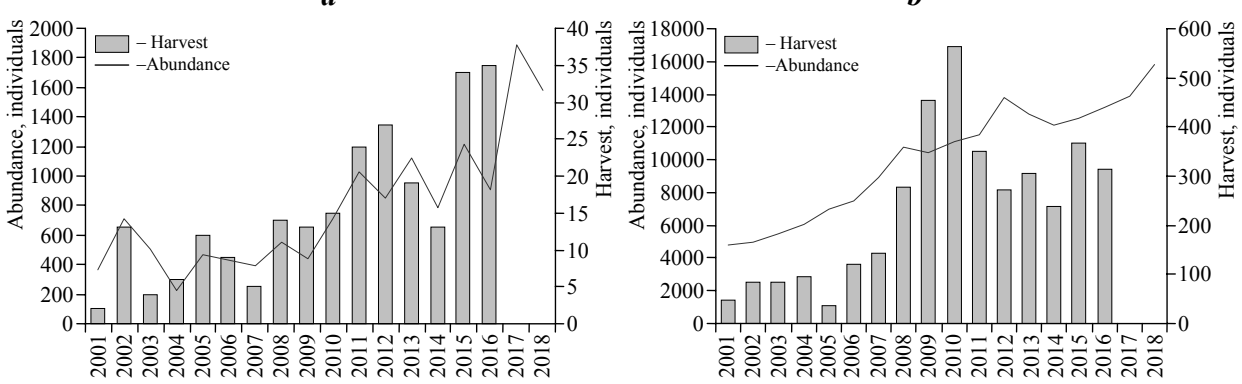

$c$

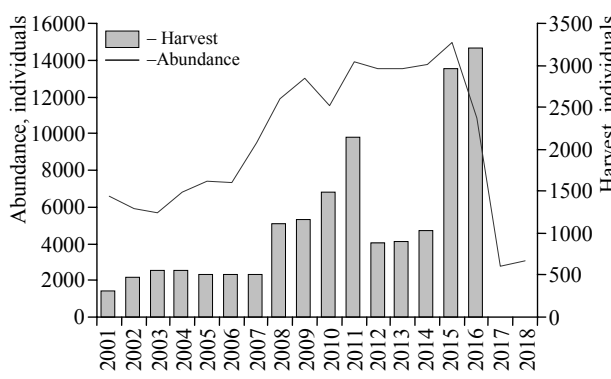

$\boldsymbol{e}$

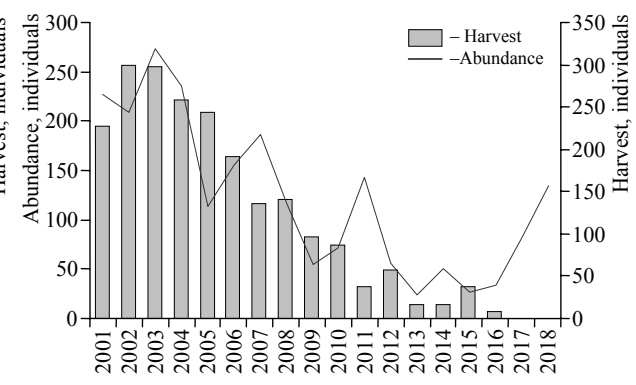

$f$

Fig. 1. Dynamics of abundance and harvest of wild ungulates and wolves in the Saratov Region at the beginning of XXI century: $a$ - elk, $b$ - red deer, $c$ - axis deer, $d$-Tartarian roe, $e$-wild boar,

$$
f \text {-wolf }
$$

We have analyzed the influence of several factors, both natural and anthropogenic, on the dynamics of the number of studied species. First of all, the impact of official prey of game species on their numbers was considered. The hunting quotas for elk, deers and Tatarian roe on the territory of Russian Federation and, accordingly, in the Saratov Region, are based on the withdrawal of a certain proportion of animals from their total number. The procedure of determining the number of individuals to be removed from the population is strictly regulated by the current legislation on hunting. Until recently, wild boar shooting was regulated in the same way as other ungulates. However, with the development of epizootic of African swine fever in the Russian Federation, regulation of 
wild boar shooting was canceled in various regions of Russia, including the Saratov Region, where year-round depopulation measures were taken. As for the wolf, its harvest is not currently standardized, but is limited only by the timing of hunting. The relative volumes of ungulates and wolf harvest on the territory of the Saratov Region for the period from 2001 to 2018 are presented in Table 1.

In general, the intensity of official prey of wild ungulates during the period under consideration is small: for elk, deers and roe, on average, it is less than 3 percent of their post harvest numbers. The intensity of wild boar hunting until 2015 was also low, about 8.5 percent, and only in the next two years, the intensity of shooting of this species significantly increased to 30 percent of its post-harvest numbers. Attention is drawn to the high intensity of the wolf's harvest, on average, more than 100 percent of its post-harvest numbers. This can be explained by the fact that the winter field records do not adequately represent the real number of this species in the territory of the Saratov ReTable 1. Parameters of harvested game animals in relation to their numbers in the Saratov Region for the period from 2001 to 2018

\begin{tabular}{l|c|c|c}
\hline \multirow{2}{*}{ Species } & \multicolumn{3}{|c}{$\begin{array}{c}\text { The actual harvest of animals as a } \\
\text { percentage of post-harvest numbers, \% }\end{array}$} \\
\cline { 2 - 4 } & $\min$ & $\max$ & average \\
\hline Elk & 1.48 & 5.10 & 2.76 \\
\hline Red deer & 1.11 & 3.62 & 2.16 \\
\hline Axis deer & 0.56 & 3.87 & 2.29 \\
\hline Roe & 0.53 & 5.07 & 2.45 \\
\hline Wild boar & 4.77 & 29.6 & 11.0 \\
\hline Wolf & 24.2 & 213.2 & 108.8
\end{tabular}
gion. Comparison of data from the winter field record with expert estimates of the number of wolves in the period of its lowest values, from 2013 to 2016, shows that the actual number of this predator is approximately two to three times higher than the accounting data. In our opinion, this is most likely due to incorrect determination of the corresponding conversion factor for the Saratov Region.

So, during periods of growth of ungulate populations, their official harvest was characterized by low intensity, and its volume was determined by the number of animals, which is reflected in the positive correlation between these values (Table 2). We explain the lack of correlation between the volume of prey and the number of elk by the reasons of an administrative nature, which are most apparent when planning and organizing the removal of this species.

Thus, changes in the harvest of ungulates cannot be the cause of the observed increase in their numbers. The intensity of the wolf's elimination was high, even considering the underreporting of its numbers. We cannot definitely say that the dynamics of the number of wolves on the territory of the Saratov Region at the beginning of this century was deter-

Table 2. The dependence of the harvest of wild ungulates and wolves on their numbers

\begin{tabular}{l|c}
\hline \multicolumn{1}{c|}{ Species } & Correlation coefficient \\
\hline Elk & 0.45 \\
\hline Red deer & $\mathbf{0 . 7 3}$ \\
\hline Axis deer & $\mathbf{0 . 8 4}$ \\
\hline Roe & $\mathbf{0 . 7 6}$ \\
\hline Wild boar & $\mathbf{0 . 6 0}$ \\
\hline Wolf & $\mathbf{0 . 8 6}$
\end{tabular}

Note. Correlation coefficients that are significantly different from zero at $p<0.05$ are highlighted in bold. mined by the intensity of its shooting, but that such an impact has been made is obvious. 
The impact of predators, wolves in particular, on the population of ungulates is beyond question (Nikolaev, 1997; Danilkin, 2006, 2007; Bondarev et al., 2013; Melnikov V. K., Melnikov V. V., 2016). It is important to find out what the impact is and whether the decline in the number of wolves from 2001 to 2016 is not the cause of the increase in abundance of ungulates at the same time. The noted earlier asynchrony in the dynamics of ungulate and wolf populations gives all the reasons for this. However, the number of wolfs in the Saratov Region is insignificant and can not have a marked impact on the number of ungulates. Thus, the ratio of predator-prey was 1:61 in the period of the greatest number of wolves and the smallest number of ungulates (2001-2003), 1: 871 in the period of the smallest number of wolf and the largest number of ungulates (20142016), and 1: 324 at present (2016-2018). The ratios presented above will not fundamentally change, if it is recognized that the official number of wolf is underestimated by two or three times.

Mathematical modeling of the predator-prey relationship shows that the prey number will be slightly below the level of the environmental capacity if the habitat conditions for the prey are above average and the predator density is low (Riklefs, 1979). In this case, the reduction in the number of the predator will not have a significant effect on the population density of its victim, since its population size will be regulated mainly by food resources and other environmental parameters.

The living conditions of ungulates in the Saratov Region generally correspond to the above model, so the growth of their numbers is most likely the result of some other factor that increased the capacity of the habitat. In this context, the reduction of the wolf population should be considered as an accompanying or additional to the main factor in the growth of ungulates abundance.

There are no direct data on the number of annually lost ungulates in the Saratov Region. There is information about the registered facts of the death of these animals from various causes. Further analysis is based on the assumption that with unchanged conditions of search, detection and registration, the number of detected cases of death of wild ungulates is directly proportional to the total number of lost animals. All identified cases of death of ungulates were divided into two groups: these are illegal taking, and animals killed as a result of other causes (diseases, injuries, mutilation, accidents, wolf predation, etc.). Due to an epizootic of African swine fever among boars that occurred at the end of the period under review, the identification of cases of their death as a result of other causes was analyzed separately from other ungulate species.

Regression analysis showed no significant changes in the number of detected cases of illegal harvest of ungulates during the period under consideration. There is about a constant amount of death of these animals from poaching for the considered period of time. The number of identified deaths of elk, deer and roe as a result of other causes significantly reduced during the period from 2001 to $2016(p<0.01)$.

For the first time, the massive death of a wild boar in the Saratov Region was registered in the first quarter of 2003, when about hundred animals died in Volsky and Voskresensky Districts allegedly from food poisoning, but it was not possible to establish the exact cause of their death. The mass death of wild boar in 2015 and 2016 occurred as a result of an epizootic of African swine fever. The number of cases of boar death as a 


\section{POPULATION DYNAMICS OF UNGULATES AND WOLVES}

result of other reasons also significantly reduced during 2001-2014 $(p<0.01)$, if we exclude the years with the mass loss of animals. The results of the correlation analysis of the number of detected cases of death of ungulates and their numbers are presented in Table 3 .

There is no correlation between the number of detected cases of illegal harvest of ungulates and their numbers. Therefore, we can conclude that the death of these animals from poaching in the territory of the Saratov Region did not have a significant effect on the dynamics of their numbers during the period under consideration.

Table 3. Dependence of registered deaths of wild ungulates on their abundance

\begin{tabular}{l|c}
\hline \multicolumn{1}{c|}{ Cause of death } & Correlation coefficient \\
\hline Poaching & -0.01 \\
\hline Other death without boar & $\mathbf{- 0 . 8 7}$ \\
\hline Other death with boar* & $\mathbf{- 0 . 9 5}$
\end{tabular}

Note. Correlation coefficients that are significantly different from zero at $p<0.01$ are highlighted in bold;* - the period from 2001 to 2014 , without 2003.

The correlation between the number of detected deaths of ungulates as a result of other causes and their abundance is negative and statistically significant. In this regard, two questions arise. Whether the reduction in the number of detected deaths of ungulates for reasons other than poaching is a result of a real reduction in the deaths of animals for these reasons? If the answer to the first question is positive, then doesn't the indicated decrease in the death of animals the reason for the increase in their numbers over the considered period?

The decrease in the number of detected cases of death of ungulates for reasons other than poaching may well be due to a decrease in the quality of monitoring of such cases on the part of specially authorized state bodies. However, one cannot exclude the process of a real reduction in the death of animals, at least by reducing the wolf's predation as a result of its low abundance. However, the reduction in the death of ungulates as a result of other causes was hardly the reason for the increase in their abundance at the beginning of this century. Most likely, the reduction of their death is a consequence of factors that caused an increase in the capacity of their habitat. As a result, intraspecific competition and animal death due to this competition decreased.

The formation of private hunting grounds on the territory of the Saratov Region began in 2000. At the beginning of 2001 there were 14 such estates with a total area of 326.6 thousand hectares. By 2010 there were already 86 estates, with a total area of 1516.9 thousand hectares. By this year, the stage of intensive assignment of hunting grounds to private hunting users was completed, and then minor changes took place (Fig. 2). There were 93 private hunting estates with an area of 1566.7 thousand hectares at the beginning of 2018 in the Saratov Region. This represents only about 15 percent of the total area of the Saratov Region, but more than 60 percent of the forested lands is concentrated within the boundaries of these estates.

The transfer of a significant part of hunting grounds to private hunting users led to a significant increase in the number of workers in the hunting estates (gamekeepers and game hunters), their equipment with vehicles, and an increase in the costs of biotechnical measures, especially feeding of game animals. Of course, this had a positive effect on the status of game animal populations. 
Considering the fact that the response of animals to improved or deteriorated habitat may happen with some delay, the time series of the total area of "private" hunting estates consistently shifted to the right relative to the increase of abundance of hunting animals

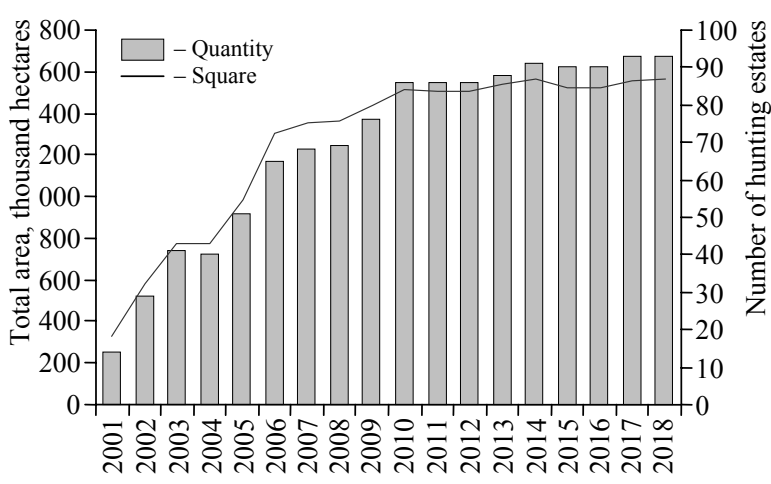

Fig. 2. The transfer of possession of hunting grounds to private hunting estates in the territory of the Saratov Region for the period from 2001 to 2018 for a year, two, etc., starting with 2001 to 8 years. Correlation analysis was conducted separately for each stage, its results are presented in Table 4.

All time series of ungulate numbers have statistically significant positive correlation with the time series of the total area of private hunting estates, and for the wolf a negative correlation for the wolf (see Table 4). The absolute values of the correlation coefficients for all animal species increase from the beginning, then decrease as the time series of the total area shifts relative to the time series of numbers. The maximum absolute values of the coefficient are observed for the elk and axis deer in the sixth year after the beginning of the formation of private hunting estates in 2000 , for the red deer in the seventh year, for roe deer, wild boar and the wolf in the third year.

Table 4. The dependence of ungulate abundance from the total area of private hunting estates

\begin{tabular}{l|c|c|c|c|c|c|c|c|c}
\hline \multirow{2}{*}{ Species } & \multicolumn{10}{|c}{ Time shift, years } \\
\cline { 2 - 11 } & 0 & 1 & 2 & 3 & 4 & 5 & 6 & 7 & 8 \\
\hline Elk & 0.73 & 0.79 & 0.85 & 0.84 & 0.86 & $\mathbf{0 . 9 0}$ & 0.87 & 0.74 & 0.79 \\
\hline Red deer & 0.76 & 0.81 & 0.77 & 0.75 & 0.81 & 0.77 & $\mathbf{0 . 8 9}$ & 0.79 & 0.67 \\
\hline Axis deer & 0.56 & 0.55 & 0.67 & 0.75 & 0.75 & $\mathbf{0 . 7 9}$ & 0.77 & 0.75 & 0.74 \\
\hline Roe & 0.90 & 0.93 & $\mathbf{0 . 9 4}$ & 0.93 & 0.91 & 0.91 & 0.89 & 0.79 & 0.76 \\
\hline Wild boar* & 0.48 & 0.94 & $\mathbf{0 . 9 8}$ & 0.94 & 0.90 & 0.91 & 0.89 & 0.71 & $\underline{0.70}$ \\
\hline Wolf & -0.80 & -0.77 & $\mathbf{- 0 . 8 5}$ & -0.79 & -0.56 & -0.58 & -0.58 & $\underline{-0.32}$ & $\underline{0.02}$
\end{tabular}

Note. Correlation coefficients are underlined that do not reliably different from zero when $p<0.05$; bold type indicates the largest in absolute value correlation coefficients; ${ }^{*}-$ only the population growth phase up to 2015 inclusive was taken into account.

Now consider the influence of natural and climatic factors on the number of ungulates. The most important of these are those that affect the forage capacity of the land and the availability of natural food for ungulates in winter.

The productivity of various forage plants depends on the combined effect of temperature and precipitation during their growing season. It is noted that in dry years the amount of food decreases significantly, and its quality deteriorates. The opposite situation is observed in wet moderately warm or cool years (Lomanov, 1995; Yeljord, 1990). The dependence of the number of wild ungulates on temperature and precipitation in the 
spring-summer and winter periods in some regions of the Russian Federation was established (Revutskaya, 2012; Domanov et al., 2016). Unfortunately, we did not find publications describing the productivity of natural forage plants in the Saratov Region. Therefore, similar to I. K. Lomanov (1995), as an index of vegetation productivity we used the yield of grain crops (Fig. 3).

Five cereal crops most common for the Saratov Region were combined into two groups: winter and spring. The yield of these agricultural crops within the selected groups does not differ significantly. At the same time, the yield of crops from different groups differs significantly $(p<0.01)$. Each of the selected groups of crops reflects in a certain way the natural and climatic conditions of the ungulate habitation during the year preceding the number counting.

The yield of all selected crops on average remained unchanged during the considered period, but it is possible to select the time period from 2011 to 2017 for the group of winter crops when their productivity increased significantly. This may indicate a slight increase in the feeding capacity of the land
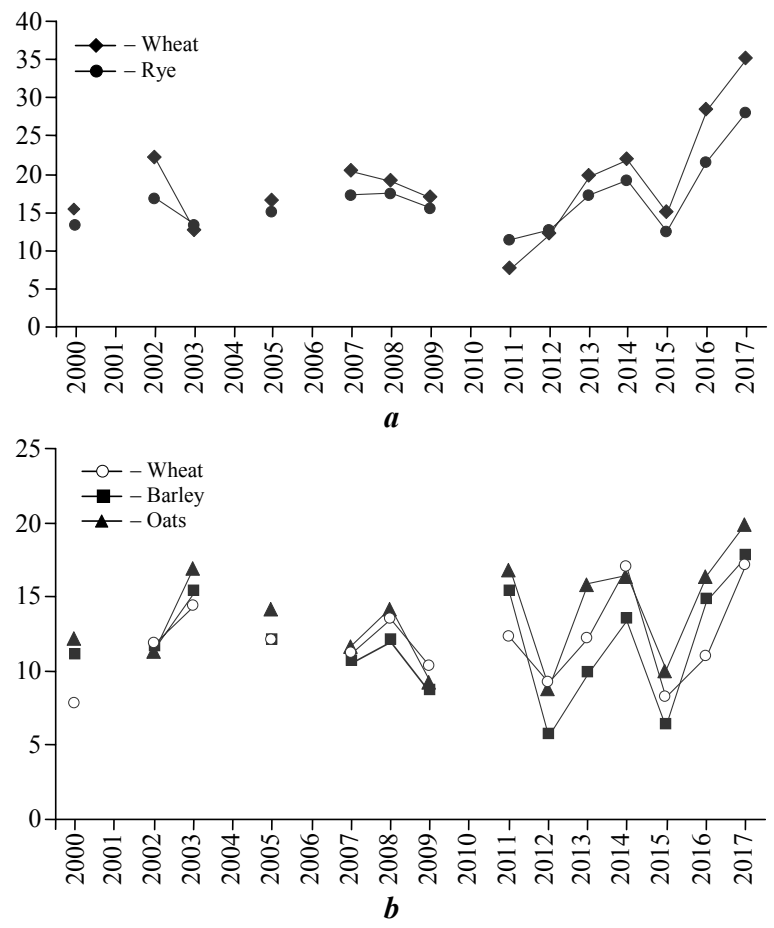

Fig. 3. Dynamics of yield of grain crops in the Saratov Region, centners from 1 ha: $a$ - winter crops, $b$-spring crops by the end of the period under consideration. However, by this time, the growth in the numbers of most species of wild ungulates began to slow down (elk, red deer, roe deer), or was already completed (wild boar). Only abundance of the axis deer reached its highest values. Apparently, this explains the positive correlation between its abundance and the yield of winter crops $(p<0.05)$. At the same time, this relationship is unstable, and the statistical significance of the correlation coefficients disappears, if we exclude from the review data on the yield of winter crops for 2017. All this suggests that the observed synchronism of the indicated dynamic series is random coincidence.

As factors that can significantly affect the availability of forage, we considered the periods with constant snow cover and the depth of snow cover. Taking into account that the effect of the indicated factors on the number of animals can be shifted in time, data from the winter of 1990-1991 were also considered. The averaged values of the selected factors over 8 meteorological stations (Rtishchevo, Balashov, Oktyabrsky Gorodok, Er- 
shov, Novouzensk, Saratov Region, Ternovka of Penza Region, Bezenchuk of Samara Region, and Uryupinsk of Volgograd Region) are shown in Figure 4.

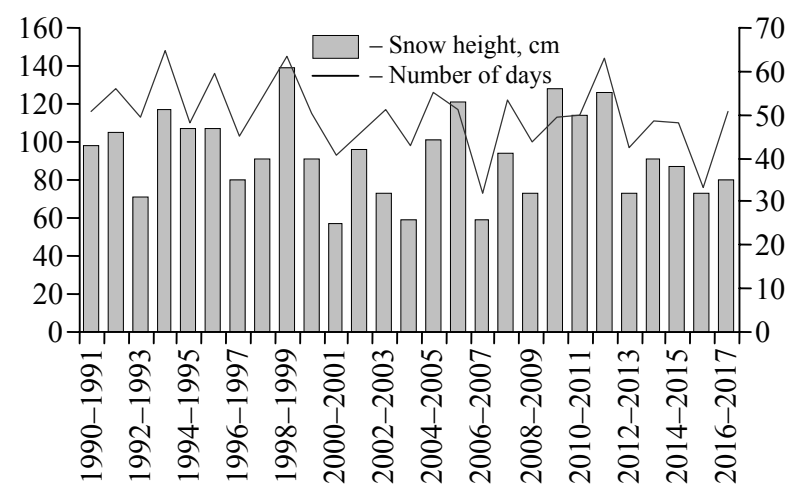

Fig. 4. Duration of periods with constant snow cover and snow depth over the past 27 years

Duration of the period with constant snow cover and the depth of snow cover, have positive correlation $(r=0.58$, $p<0.01)$. Therefore, we must regard them as different signs of the same factor. At the same time, the period with constant snow cover has declined significantly over the past 27 years by about 20 days $(p<$ $<0.05)$. We could not establish the reliability of reducing the depth of snow cover. Perhaps this is due to the greater variability of this characteristic compared with the previous one. However, given the previously established direct correlation between these two signs, it can be expected that the depth of snow cover during this time also slightly decreased. The revealed changes in the indicated natural parameters turned out to be correlatively unrelated to changes in the number of ungulates, both during direct comparison and with their shift relative to each other for a number of years.

\section{CONCLUSION}

Thus, of all the factors considered, only one influenced directly the population dynamics of wild ungulates in the Saratov Region at the beginning of this century. A very strong direct correlation between the increase in the area of hunting grounds assigned to private users and the increase in the number of wild ungulates certainly indicates their cause-and-effect relationship. As a result of the development of private hunting management, vast areas with intensive biotechnology, improved protection and very moderate use of wild ungulate resources appeared in the Saratov Region, which include main forested lands. In addition, in these territories, mass hunting for fur animals, including coursing, is significantly limited. This can be regarded as a reduction in additional disturbance. Consequently, the actual capacity of the habitat of these animals increased, which led over time to an increase in their abundance. Wild boar and roes' populations responded to the improvement of external conditions most quickly. After the acquisition of hunting grounds, new owners immediately began to feed the boars, and not only in winter, but also in summer, in order to distract animals from agricultural crops. The boar population very quickly responded to this by rapid growth.

There are no special actions for feeding roe deer in the region. Therefore, considerable time lag was to be expected till their abundance begin to grow. In reality this species responded much earlier. Reaction of related species (elk and deer) has a time lag of 6-7 years. This can be explained as follows: at the beginning of the 1990s, large agricul- 


\section{POPULATION DYNAMICS OF UNGULATES AND WOLVES}

tural enterprises in the Saratov Region ceased operations, and huge areas of arable land transformed into a tangle of the weedy demutation stage, which were very favorable for the roe deer, and contributed to the rapid growth of its abundance (Oparin, 2007).

Despite the great importance of the correlation coefficient, we were unable to establish a link between the increase in the area of hunting grounds assigned to private owners, and the reduction of the wolf population. The increase in the area of private grounds did not lead to an increase in the intensity of the predator's harvest. It is quite possible that the reason for the decrease in its number was some factors not considered in this study.

It should be noted that the "private" hunters sought to get the best hunting grounds, primarily forest areas. In the Saratov Region, most of these lands were assigned to them by 2010 , and the process of formation of private hunting grounds was generally completed. In this regard, it is to be expected that the growth of population density of wild ungulates observed now will also cease in the near future.

\section{Acknowledgments}

This work was supported by the Russian Foundation for Basic Research (project no. 16-05-00488) (30\%) and by the Presidium of the Russian Academy of Sciences "Biodiversity of Natural Systems and Biological Resources of Russia" (project no. 0109-20180067 «Regularities of Biodiversity Changes in Anthropogenic-transformed Ecosystems») (20\%) and the planned research topic (project no. 0109-2018-00010) (50\%).

\section{REFERENCES}

Bondarev A. Ya., Zhuravlev V. B., Petrov V. Yu. The dynamics of the wolf and elk abundance in western Siberia. Bulletin of the Altai State Agrarian University, 2013, no. 7 (105), pp. 5662 (in Russian).

Caughley G.. Analysis of Vertebrate Populations. Moscow, Mir Publ., 1979. 362 p. (in Russian).

Danilkin A. A. Wild Ungulates in the Hunting Economy (Foundations of Resource Management). Moscow, GEOS Publ., 2006. 366 p. (in Russian).

Danilkin A. A. To the problem of "cyclicity" in the dynamics of the number of wild ungulates. The Herald of Game Management, 2007, vol. 4, no. 1, pp. $89-99$ (in Russian).

Danilkin A. A. Population Dynamics of Wild Ungulates in Russia: Hypotheses, Factors, Patterns. Moscow, KMK Scientific Press Ltd., 2009. 310 p. (in Russian).

Domanov T. A., Podolsky S. A., Krasikova E. K. The role of some climatic factors in the dynamics of the number of the wolf and its hunting objects on the territory of the Zeya Reserve. Climate, Ecology, Agriculture of Eurasia: Materials of the V International Scientific and Practical Conference. Irkutsk, Irkutsk State Agrarian University named after A.A. Ezhevsky, 2016, pp. 179184 (in Russian).

Federal Service for Hydrometeorology and Environmental Monitoring All-Russian Research Institute of Hydrometeorological Information - the World data center. Moscow, 2018. Available at: http://www.meteo.ru/data/ (accessed 15 July 2018).

Federal State Statistics Service. Moscow, 2018. Available at: http:// http://www.gks.ru (accessed 10 July 2018).

Kontseptsiya razvitiya agropromyshlennogo kompleksa Saratovskoy oblasti do 2020 goda (The concept of development of the agro-industrial complex of the Saratov Region until 2020). Saratov, 2018. Available at: http://www.minagro.saratov.gov.ru/Razvitie/ (accessed 10 July 2018). 
Mikhail L. Oparin, Igor A. Kondratenkov, Olga S. Oparina et al.

Lomanov I. K. Zakonomernosti dinamiki chislennosti i razmeshcheniya naseleniya losya $v$ evropeyskoy chasti Rossii [Patterns of the dynamics of the number and distribution of the moose population in the European part of Russia]. Moscow, TsNIL Okhotdepartamenta MSKhiP RF, 1995. 60 p. (in Russian).

Melnikov V. K., Melnikov V. V. To feed the wolf in the Baikal region. Climate, Ecology, Agriculture of Eurasia: Materials of the V International Scientific and Practical Conference. Irkutsk, Irkutsk State Agrarian University named after A.A. Ezhevsky, 2016, pp. 252-255 (in Russian).

Oparin M. L. Antropogennaya transformatsmya i estestvennoye vosstanovleniye bioty selskokhozyaystvennykh landshaftov Nizhnego Povolzhia i Zakavkazia [Anthropogenic Transformation and Natural Restoration of Biota in Agricultural Landscapes of the Lower Volga and Transcaucasia]: Thesis Diss. Dr. Sci. (Biol.). Moscow, 2007. 48 p. (in Russian).

Revutskaya O. L. Analiz vliyaniya klimaticheskikh faktorov na dinamiku chislennosti kopytnykh (na primere Evreyskoy avtonomnoy oblasti) [Analysis of the influence of climatic factors on the dynamics of the number of ungulates (for example, the Jewish Autonomous Region)]. In: Fundamentalnyye $i$ prikladnyye issledovaniya $v$ matematicheskoy ekologii i agroekologii: materialy mezhdunarodnoy shkoly-seminara [Fundamental and Applied Research in Mathematical Ecology and Agroecology: Materials of the International School Seminar]. Barnaul, Altai State University, 2012, pp. 132-135 (in Russian).

Riklefs R. Basics of General Ecology. Moscow, Mir Publ., 1979. 424 p. (in Russian). Russian).

Watt K. Ecology and Natural Resource Management. Moscow, Mir Publ., 1971. 463 p. (in

Yeljord O. Summer Feeding Strategy of Elk. Third International Symposium on Elk. Syktyvkar, Komi Scientific Center, Ural Branch of the Russian Academy of Sciences, 1990, pp. 32. 


\title{
ФАКТОРЫ ДИНАМИКИ ЧИСЛЕННОСТИ КОПЫТНЫХ И ВОЛКА В САРАТОВСКОЙ ОБЛАСТИ В ХХІ ВЕКЕ
}

\author{
М. Л. Опарин ${ }^{1}$, И. А. Кондратенков ${ }^{1}$, О. С. Опарина ${ }^{1}$, \\ С. В. Сухов ${ }^{2}$, А. Б. Мамаев ${ }^{1}$ \\ ${ }^{1}$ Саратовский филиал Института проблем экологии и эволюичии \\ им. А. Н. Севериова РАН \\ Россия, 410028, Саратов, Рабочая, 24 \\ ${ }^{2}$ Комитет охотничьего хозяйства и рыболовства Саратовской области \\ Россия, 410012, Саратов, Университетская, 47-55 \\ E-mail:oparinml@mail.ru
}

Поступила в редакцию 28.07.2018 г., после доработки 16.08.2018 г., принята 29.08.2018 г.

Oparin M. L., Kondratenkov I. A., Oparina O. S., Sukhov S. V., Mamaev A. B. Population Dynamics Factors of Ungulates and Wolves of the Saratov Region in the $21^{\text {st }}$ Century [Опарин М. Л., Кондратенков И. А., Опарина О. С., Сухов С. В., Мамаев А. Б. Факторы динамики численности копытных и волка в Саратовской области в XXI веке] // Поволжский экологический журнал. 2018. № 4. C. 433 - 446. DOI: https://doi.org/10.18500/1684-7318-2018-4-433-446

Статья посвящена изучению связей между формированием «частных» охотничьих хозяйств, ростом плотности копытных и снижением численности волка, а также роли других факторов в динамике обилия этих охотничьих животных. В Саратовской области постоянно обитают шесть видов копытных: лось, олень европейский, олень пятнистый, косуля европейская, косуля сибирская и кабан. Все виды, кроме косули европейской, являются промысловыми. Косуля европейская редкий вид, занесенный в Красную книгу Саратовской области. Динамика численности популяций копытных и волка на территории описываемого региона изучена по данным зимних маршрутных учетов, а также их официальной добычи за период с 2001 по 2018 г. Население всех видов копытных за рассматриваемый период времени существенно увеличилось, а численность волка, наоборот, уменьшилась. Нами был проведен анализ влияния ряда факторов, как природных, так и антропогенных, на динамику численности указанных видов. В первую очередь рассматривалось влияние официальной добычи охотничьих видов на их численность. Из всех рассмотренных нами факторов можно выделить только один, непосредственно повлиявший на динамику популяций диких копытных животных в Саратовской области в начале текущего столетия. Очень сильная прямая корреляция между увеличением площади охотничьих угодий, закрепленных за «частными» охотпользователями, и ростом численности диких копытных, безусловно, говорит об их причинно-следственной связи.

Ключевые слова: «частные» охотничьи хозяйства, копытные, волк, динамика численности охотничьих животных, природные и антропогенные факторы.

DOI: https://doi.org/10.18500/1684-7318-2018-4-433-446 
Mikhail L. Oparin, Igor A. Kondratenkov, Olga S. Oparina et al.

Благодарности. Работа выполнена при финансовой поддержке Российского фонда фундаментальных исследований (проект № 16-05-00488) (30\%), Программы Президиума РАН «Биоразнообразие природных систем и биологических ресурсов России» (проект № 0109-2018-0067 «Закономерности изменения биоразнообразия в антропогенно-трансформированных экосистемах») (20\%) и плановой научной темы (проект № 0109-2018-00010) $(50 \%)$. 